\title{
Učestalost i raspodjela kalcificiranosti ilijačnih arterija u pacijenata u kojih je učinjena transplantacija bubrega
}

\section{Incidence and distribution of iliac arteries calcifications in the patients with kidney transplantation}

\author{
Iva Žuža ${ }^{1}$, Doris Dodig ${ }^{1}$, Dorian Tokmadžić ${ }^{2}$, David Zgrablić2 ${ }^{2}$ Edina Ferizović ${ }^{2}$ Ivan Vukelić ${ }^{3}$, \\ Damir Miletić, ${ }^{1,2}$, Lidija Orlić, ${ }^{2,4}$, Dean Markić2,3*
}

${ }^{1}$ Klinički zavod za radiologiju, Klinički bolnički centar Rijeka, Rijeka, Hrvatska

${ }^{2}$ Medicinski fakultet Sveučilišta u Rijeci, Rijeka, Hrvatska

${ }^{3}$ Klinika za urologiju, Klinički bolnički centar Rijeka, Rijeka, Hrvatska

${ }^{4}$ Zavod za nefrologiju, dijalizu i transplantaciju, Klinički bolnički centar Rijeka, Rijeka, Hrvatska

\author{
"Dopisni autor: \\ Izv. prof. dr. sc. Dean Markić, dr. med. \\ Klinika za urologiju Medicinskog fakulteta \\ Sveučilišta u Rijeci, Klinički bolnički centar \\ Rijeka, Tome Strižića 3, 51000 Rijeka \\ E-mail: dean.markic@ri.htnet.hr
}

Sažetak. Cilj: Prikazati učestalost i raspodjelu kalcificiranosti ilijačnih arterija u pacijenata u kojih je učinjena transplantacija bubrega u našem transplantacijskom centru. Ispitanici $i$ metode: Retrospektivnim istraživanjem bili su obuhvaćeni pacijenti u Kliničkom bolničkom centru Rijeka u kojih je između 1. siječnja 2015. godine i 31. prosinca 2018. godine učinjena transplantacija bubrega. Procjena kalcificiranosti ilijačnih arterija učinjena je uz pomoć kompjutorizirane tomografije (CT). Rezultati: $\cup$ promatranom razdoblju u našem transplantacijskom centru učinjeno je 115 transplantacija bubrega, a 92 (80\%) pacijenata imalo je prijeoperacijski CT. Prosječna dob pacijenata bila je 60,3 godina, a $26 \%$ pacijenata je imalo šećernu bolest kao osnovnu bolest. Arterijske kalcifikacije pronađene su u 72 (78\%) pacijenata. Kalcifikacije su najčešće pronađene na desnoj zajedničkoj ilijačnoj arteriji (63 pacijenata $-68,5 \%$ ), a najrjeđe na lijevoj vanjskoj ilijačnoj arteriji ( 23 pacijenta $-25 \%$ ). Zaključak: Većina naših pacijenata ima prisutne kalcifikacije na ilijačnim arterijama. Prijeoperacijsko utvrđivanje njihove raspodjele i proširenosti ima važnu ulogu prilikom planiranja transplantacije bubrega.

Ključne riječi: kalcifikacije; transplantacija bubrega; vaskularne komplikacije

Abstract. Aim. To evaluate the incidence and distribution of calcifications of iliac arteries in patients with kidney transplantation in our transplant center. Patients and Methods. We retrospectively analyzed patients with kidney transplantation operated at University Hospital Rijeka from January $1^{\text {st }} 2015$ to December $31^{\text {st }} 2018$. The assessment of iliac arteries calcifications was made using computed tomography. Results. In observed period 115 kidney transplantations were performed in our transplant center and $92(80 \%)$ of patients had preoperative CT scan. The average age was 60,3 years and $26 \%$ of patients had diabetes mellitus as principal disease. Arterial calcifications were found in $72(78 \%)$ patients. The calcifications were most common in the right common iliac artery $(63 \mathrm{pts}-68,5 \%)$ and rarest in left external iliac artery (23 pts - 25\%) Conclusion. Most of our patients have calcifications of iliac arteris. Preoperative assessment of their distribution and extent had a very important role in the planning of kidney transplantation.

Key words: calcifications; kidney transplantation; vascular complications

http://hrcak.srce.hr/medicina 


\section{UVOD}

Metode nadomještanja bubrežne funkcije su: hemodijaliza, peritonejska dijaliza i transplantacija bubrega. U Republici Hrvatskoj su 2014. godine bila 4102 pacijenta na nadomjesnoj terapiji bubrežne funkcije ${ }^{1}$. Od toga je 2051 (50 \%) bio na hemodijalizi, 117 (2,8\%) bilo je na peritonejskoj dijalizi, a 1934 (48,2 \%) su imala funkcionirajući transplantat. Od svih gore navedenih metoda transplantacija bubrega najučinkovitija je jer značajno povećava preživljenje pacijenata, unaprjeđuje njihovu kvalitetu života, a i financijski je najisplativija. Primatelji bubrežnog transplantata moraju proći odgovarajuću obradu prije transplantacije. Ona uključuje široku obradu, a između ostalog i procjenu krvnih žila, kako bi se odredilo mjesto budućih vaskularnih anastomoza. $U$ velike većine pacijenata presadak se anastomozira na ilijačne krvne žile. No, kalcificiranost krvnih žila (arterija) može to spriječiti te je neophodno prije transplantacije učiniti njihovu evaluaciju.

Pacijenti s kroničnom bolešću bubrega imaju značajnu učestalost arterijskih kalcifikacija. One nastaju kao posljedica hiperparatireoidizma, šećerne bolesti i hiperkolesterolemije, a učestalost im se povećava $\mathrm{s}$ dobi ${ }^{2,3}$. Desetljećima se procjena kalcificiranosti ilijačnih krvnih žila određivala radiografskom snimkom zdjelice, a kasnije se u obradu uvrstio i ultrazvučni pregled (Color Doppler). Umjerenu i jaku prisutnost kalcificiranosti krvnih žila na radiografskoj snimci možemo pronaći u čak 40 \% pacijenata u kojih je učinjena transplantacija bubrega ${ }^{4}$. Također, prema nekim autorima, prisutnost kalcifikacija u zdjeličnim arterijama značajno smanjuje preživljenje i pacijenata i presatka te povećava šansu razvoja intraoperativnih vaskularnih komplikacija ${ }^{4}$. lako je ova metoda dostupna i lako provediva, njezin najveći nedostatak je niska senzitivnost (42\%) i specifičnost $(82 \%)^{5}$. Kompjutorizirana tomografija (CT) smatra se daleko točnijom dijagnostičkom metodom za procjenu krvnih žila te se u današnje vrijeme ona smatra zlatnim standardom za njihovu evaluaciju ${ }^{6,7}$.

Cilj ovog rada je prikazati učestalost i distribuciju kalcificiranosti ilijačnih krvnih žila u pacijenata u kojih je učinjena transplantacija bubrega.

\section{ISPITANICI I METODE}

Retrospektivno smo analizirali pacijente u kojih je od 1. siječnja 2015. godine do 31. prosinca 2018. godine u Kliničkom bolničkom centru Rijeka učinjena transplantacija bubrega. Izdvojili smo pacijente

U današnje vrijeme primatelji bubrežnog presatka sve su stariji i imaju značajne komorbiditete, a to sve utječe na visoku učestalost kalcificiranosti ilijačnih arterija. Kalcificirane ilijačne arterije mogu predstavljati značajni kirurški problem tijekom transplantacije, ali i u poslijetransplantacijskom razdoblju.

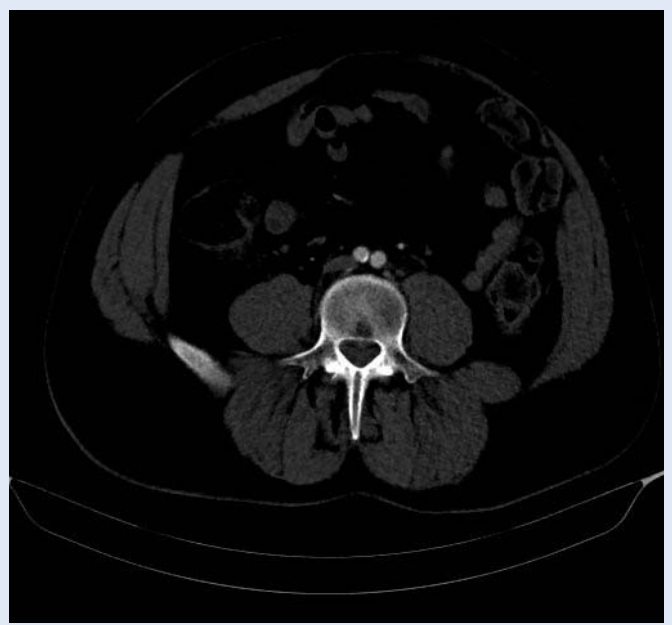

Slika 1. Nativni CT: tanka linearna kalcifikacija desne zajedničke ilijačne arterije, maksimalne debljine manje od $1 \mathrm{~mm}$, prema Davisovoj klasifikaciji M1.

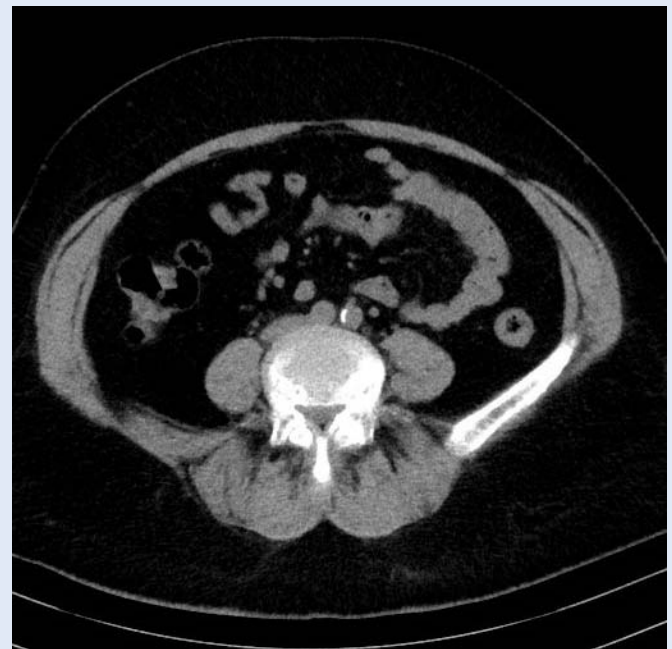

Slika 2. Nativni CT: deblja linearna kalcifikacija lijeve zajedničke ilijačne arterije, maksimalne debljine veće od $1 \mathrm{~mm}$, prema Davisovoj klasifikaciji M2. 


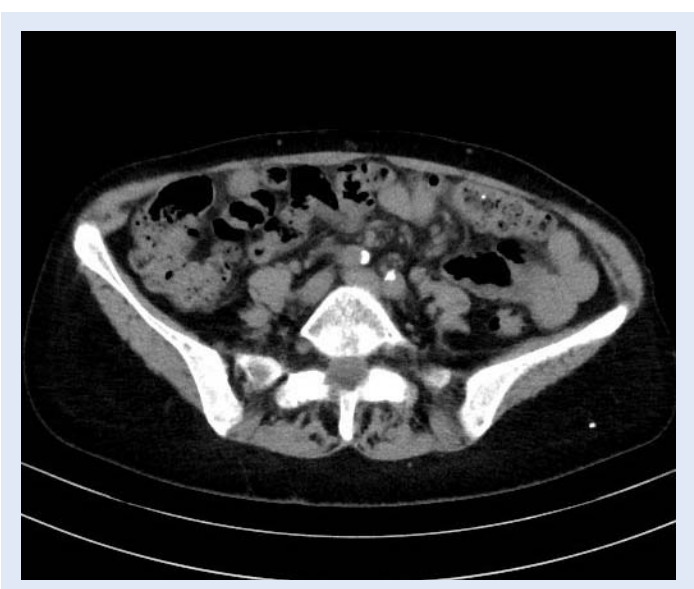

Slike 3. Nativni CT: glomazna kalcifikacija obje zajedničke ilijačne arterije, maksimalne debljine veće od $2 \mathrm{~mm}$ s konveksnim intraluminalnim rubovima, prema Davisovoj klasifikaciji M3.

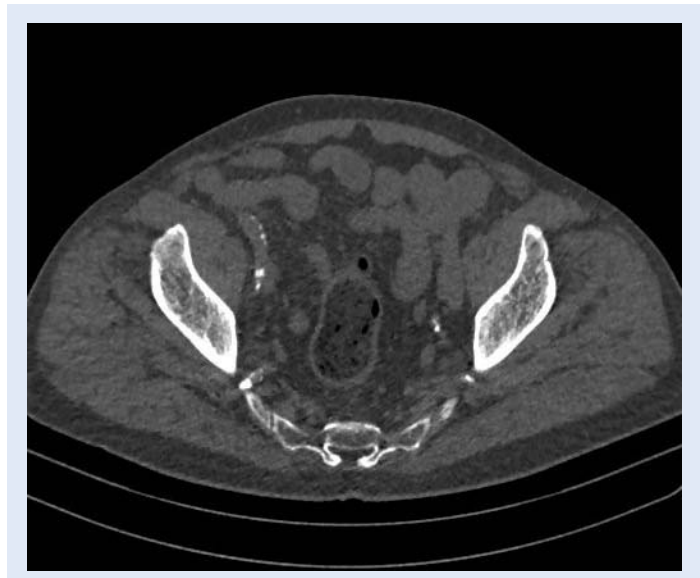

Slike 4. Nativni CT: kalcifikacije desne vanjske ilijačne arterije, duljina zahvaćenosti arterijskog segmenta je između 25 i 50 \%, prema Davisovoj klasifikaciji L2.

u kojih smo u sklopu prijetransplantacijske obrade učinili CT (nativni ili s kontrastom) abdomena i zdjelice. Iz medicinske dokumentacije odredili smo osnovne demografske i kliničke podatke.

Transplantacija je standardno učinjena u ilijačnu jamu. U pravilu smo lijevi bubreg stavljali u desno ilijačnu jamu i obrnuto, a sve s ciljem da pijelon transplantiranoga bubrega bude najpovršnija struktura. U pacijenata u kojih to nije bilo moguće (izrazite kalcifikacije ilijačnih krvnih žila, otprije prisutni transplantat) bubreg smo transplantirali na istu stranu (primjerice lijevi bubreg u lijevu ilijačnu jamu) tzv. „upside-down“ tehnikom. Ovisno o kalcificiranosti krvnih žila ili položaju presatka renalnu arteriju smo anastomozirali na vanjsku ilijačnu arteriju (većina pacijenata) ili na zajedničku ilijačnu arteriju koristeći neresorptivni konac (polipropilen, 5-0). Venu renalis smo u pravilu anastomozirali na vanjsku ilijačnu venu (polipropilenski konac, 5-0). Ureter je implantiran u mokraćni mjehur ekstravezikalnom metodom po Lich-Gregoiru. Radi sprječavanja uroloških komplikacija intraoperativno smo postavili JJ ureteralnu endoprotezu koju smo cistoskopski vadili $2-6$ tjedana nakon operacije.

Procjenu kalcificiranosti učinila su dva radiologa. Obostrano su evaluirane vanjske i zajedničke ilijačne arterije prema kriterijima vidljivim u tablici 1 i to svaki arterijski segment zasebno. Korišten je semikvantitativni sustav bodovanja kako bi se evaluirala kalcificiranost ilijačnih arterija. Sustav ocjenjivanja temeljen je na procjeni morfologije, opsega i duljini kalcifikacijama zahvaćenom arterijskom segmentu, koji su razvili Davis i suradnici. Odredili smo učestalost i raspodjelu kalcifikacija te kalcifikacijski zbroj po određenom arterijskom segmentu.

\section{Statistička analiza}

Statističku obradu podataka učinili smo standardnim metodama uporabom kompjutorskog programa Statistica 13.5.0.17 (TIBCO Software, Palo



Slika 5. CT s kontrastom (uz rekonstrukciju krvnih žila): lijeva vanjska ilijačna arterija je potpuno kalcificirana te je kod pacijenata učinjena transplantacija u desnu ilijačnu jamu korištenjem desne vanjske ilijačne arterije. 
Alto, CA, USA). Podaci su prikazani apsolutnom i relativnom učestalošću (frekvencijom i postocima).

\section{REZULTATI}

U razdoblju od 1. siječnja 2015. godine do 31 . prosinca 2018. godine učinili smo ukupno 115 transplantacija bubrega. U 92 (80\%) pacijenata imali smo prijeoperacijski CT abdomena i zdjelice koji smo i analizirali. U preostala 23 pacijenta CT nije učinjen (pacijenti mlađe životne dobi) ili do njega nismo uspjeli doći (CT učinjen u drugoj ustanovi). Od 92 pacijenta koja su imala CT u 78 pacijenata učinjen je s kontrastom, a u 14 pacijenata učinjen je nativni CT.

Prosječna dob pacijenata bila je 60,3 godine (medijan 60 godina), a raspon dobi 29 - 80 godina. Osnovni demografski i klinički podaci vidljivi su iz tablice 2. Prosječno trajanje hladne ishemije je bilo 15 sati i 45 minuta (raspon 4 sata i 7 minuta do 30 sati).

Od sveukupno 92 pacijenta, 38 transplantacija napravljeno je na desnu stranu, a 54 transplanta- cija napravljeno je na lijevu stranu. Od 54 transplantacija napravljenih na lijevoj strani - u 4 pacijenta je lijevi bubreg transplantiran lijevo, a u 50 pacijenata je desni bubreg transplantiran lijevo. Od 38 transplantacija napravljenih na desnoj strani - u 7 pacijenata je desni bubreg transplantiran desno, u 30 pacijenata je lijevi bubreg transplantiran desno, a u jedne pacijentice napravljena je en-bloc operacija.

Uzroci ipsilateralne transplantacije (11 pacijenata) bili su: izrazite kalcifikacije ilijačnih arterija na kontralateralnoj strani dokazane CT-om (5 pacijenata), transplantacija uz korištenje urinarne diverzije (1 pacijent), policistična bolest bubrega (1 pacijent), velika lumbocela (1 pacijent), hipotrofična vanjska ilijačna vena (1 pacijent), postojeći transplantat (1 pacijent) i prethodno operiran tumor zdjelice $s$ anus preterom (1 pacijent).

Od ukupno 92 pacijenta njih 72 (78\%) imalo je arterijske kalcifikacije na nekoj od analiziranih krvnih žila. Od ukupno analizirana 368 arterijskih segmenata njih $170(46,2 \%)$ imalo je kalci-

Tablica 1. Kriteriji podjele kalcifikacija ilijačnih arterija u tri različite kategorije evaluiranih kompjutoriziranom tomografijom.

\begin{tabular}{|c|c|}
\hline $\begin{array}{l}\text { Kategorije } \mathrm{i} \\
\text { bodovanje }\end{array}$ & Definicija \\
\hline $\begin{array}{l}\text { Morfologija } \\
\text { Kalcifikacija }\end{array}$ & Najviši stupanj kalcifikacija temeljen na izgledu i obliku \\
\hline 0 & Bez kalcifikacija \\
\hline 1 & Tanke linearne kalcifikacije, maksimalne debljine $\leq 1 \mathrm{~mm}$, poput „ljuske od jajeta“ \\
\hline 2 & $\begin{array}{l}\text { Deblje linearne kalcifikacije, maksimalne debljine }>1 \mathrm{~mm} \text { i s konveksnim vanjskim } \\
\text { rubovima }\end{array}$ \\
\hline 3 & $\begin{array}{l}\text { Glomazne kalcifikacije, maksimalne debljine }>2 \mathrm{~mm} \text { i s konveksnim intraluminalnim } \\
\text { rubovima }\end{array}$ \\
\hline Opseg kalcifikacija & Najveći postotak zahvaćenosti opsega arterijskoga segmenta \\
\hline 0 & Bez kalcifikacija \\
\hline 1 & $1-25 \%$ \\
\hline 2 & $26-50 \%$ \\
\hline 3 & $51-75 \%$ \\
\hline 4 & $76-100 \%$ \\
\hline Duljina kalcifikacija & Postotak duljine zahvaćenosti arterijskog segmenta \\
\hline 0 & Bez kalcifikacija \\
\hline 1 & $1-25 \%$ \\
\hline 2 & $26-50 \%$ \\
\hline 3 & $51-75 \%$ \\
\hline 4 & $76-100 \%$ \\
\hline
\end{tabular}

Modificirano prema Davis i sur. ${ }^{7}$ 
Tablica 2. Osnovne demografske i kliničke značajke pacijenata. ( $N=92)$

\begin{tabular}{|l|c|c|}
\hline Značajke pacijenata & N & \multicolumn{2}{|c|}{$\%$} \\
\hline Spol & 22 & 23,9 \\
\hline - žene & 70 & 76,1 \\
\hline - muškarci & 24 & 26,1 \\
\hline Osnovna bolest & 14 & 15,2 \\
\hline - šećerna bolest & 14 & 15,2 \\
- nefroangioskleroza & 9 & 9,8 \\
- kronični glomerulonefritis & 6 & 6,5 \\
- policistična bolest bubrega & 25 & 27,2 \\
\hline - kronični pijelonefritis & & \\
\hline - ostale bolesti & 50 & 54,3 \\
\hline Podrijetlo organa & 42 & 45,7 \\
\hline - Hrvatska & & \\
\hline - ostale zemlje Eurotransplanta & 549 & 52,5 \\
\hline Strana transplantacije & 496 & 47,5 \\
\hline - lijeva & & \\
\hline - desna & 34 & 36,9 \\
\hline Arterijski segment korišten za transplantaciju & 58 & 63,1 \\
\hline - desna vanjska ilijačna arterija & & \\
\hline - lijeva vanjska ilijačna arterija & & \\
\hline
\end{tabular}

Tablica 3. Prisutnost kalcifikacija i prosječni kalcifikacijski zbroj na specifičnom arterijskom segmentu. $(N=92)$

\begin{tabular}{|l|c|c|c|c|}
\hline \multirow{2}{*}{\multicolumn{1}{|c|}{ Arterijski segment }} & $\begin{array}{c}\text { Prisutnost } \\
\text { kalcifikacija }\end{array}$ & \multicolumn{3}{c|}{ Prosječni kalcifikacijski zbroj } \\
\cline { 2 - 5 } & $\mathbf{N}(\%)$ & Morfologija & Opseg & Duljina \\
\hline desna zajednička ilijačna arterija & $63(68,5)$ & 1,62 & 1,33 & 1,75 \\
\hline lijeva zajednička ilijačna arterija & $51(55,4)$ & 1,31 & 1,18 & 1,38 \\
\hline desna vanjska ilijačna arterija & $33(35,9)$ & 0,64 & 0,62 & 0,62 \\
\hline lijeva vanjska ilijačna arterija & $23(25)$ & 0,47 & 0,47 & 0,43 \\
\hline
\end{tabular}

fikacije. Kalcifikacije su bile češće na zajedničkim ilijačnim arterijama nego na vanjskoj ilijačnoj arteriji (tablica 3). Također je vidljivo da je veća učestalost kalcifikacija bila na desnoj u odnosu na lijevu stranu. Kalcifikacijski zbroj je bio najveći na zajedničkim unutarnjim arterijama (tablica 3).

Dvije arterijske anastomoze morali smo učiniti u 7 pacijenata (3 na desnu vanjsku ilijačnu arteriju i 4 na lijevu vanjsku ilijačnu arteriju).

\section{RASPRAVA}

Dob pacijenata u završnom stadiju bubrežnog zatajenja neprestano raste, pa je tako medijan dobi novih pacijenata 2014. godine u Republici Hrvatskoj bio 67 godina ${ }^{1}$.

$U$ našoj studiji je prosječna dob bila 60 godina (najstariji pacijent je imao 80 godina), a u $30 \%$ pacijenata je šećerna bolest bila osnovni uzrok bubrežnog zatajenja. S obzirom na dob i komorbiditete za očekivati je da ćemo imati sve veći broj pacijenata $s$ kalcificiranim arterijama koji će zahtijevati adekvatnu prijeoperacijsku evaluaciju krvnih žila.

Različita stručna udruženja (urološka, nefrološka, transplantacijska) preporučuju prijetransplantacijsku obradu koja je relativno široka ${ }^{8,9}$. No, iz smjernica je vidljivo kako se ne specificira način obrade krvnih žila primatelja, već je ona ostavljena na odabir svakom transplantacijskom cen$\operatorname{tru}^{8,9}$.

Promijenjene krvne žile veoma se često nalaze u pacijenata koji su potencijalni primatelji te je njihova evaluacija prije transplantacije veoma bitna. Idealno bi trebalo prikazati arterijsku i vensku 
anatomiju ilijačnih krvnih žila, kao i njihovu patologiju i pokazati je li transplantacija bubrega moguća, je li potrebno određeno liječenje prije transplantacije i koji je najbolji kirurški pristup za svakog transplantacijskog kandidata.

RTG snimka abdomena i zdjelice je zbog svoje dostupnosti, jednostavnosti i minimalnog troška dugo vremena bila osnovna pretraga za prijetransplantacijsku procjenu krvnih žila. Ultrazvuk kombiniran s dopplerskim prikazom u kombinaciji s RTG snimkom može donijeti dodatne informacije, pogotovo što se tiče njihove funkcionalnosti (protok krvi). No, ultrazvuk često nije dovoljan za adekvatan prikaz zdjeličnih krvnih žila, a pogotovo se to odnosi na procjenu kalcificiranosti zdjeličnih arterija. Također, primjena ove metode ovisi o tjelesnoj građi pacijenta uz visoku inter- i intraopserversku varijabilnost. CT, pogotovo CT angiografija, daleko bolje prikazuje aortu i ilijačne krvne žile. Na taj se način postiže bolja selekcija primatelja i točnije planiranje mjesta arterijske anastomoze ${ }^{6}$. No, ova pretraga može biti limitirana s kalcifikacijama i ne uspijeva adekvatno prikazati vensku anatomiju. Ovo posljednje je pogotovo bitno ako je pacijent za vaskularni pristup imao femoralni kateter, a što za posljedicu može imati stenozu femoralne i vanjske ilijačne vene.

Prijetransplantacijska evaluacija krvnih žila uz pomoć CT-a smatra se zlatnim standardom ali i ona ima određena ograničenja. To se prvenstveno odnosi na izloženost zračenju i jodnom kontrastnom sredstvu koja može dovesti do pogoršanja bubrežne funkcije, pa čak i do potrebe za dijalitičkim liječenjem u pacijenata koji još imaju određenu ostatnu bubrežnu funkciju ${ }^{10,11}$. U nekim centrima se, stoga, započelo s korištenjem magnetske rezonancije (MR) u procjeni kalcificiranosti krvnih žila. Osnovna prednost ove pretrage je što se izbjegava izloženost zračenju uz podjednaki prikaz krvnih žila, kao i kod CT-a. Nedostatak je duljina pretrage, dostupnost i njezina cijena te mogućnost razvoja nefrogene sistemske fibroze. Naime, kao kontrastno sredstvo koristi se gadolinijum koji može, doduše rijetko, u pacijenata $s$ kroničnom bubrežnom bolešću dovesti do nefrogene sistemske fibroze ${ }^{12}$. Obećavajući rezultati su postignuti korištenjem ferumoksitola kao kontrastnog sredstva prilikom MR pretrage. U svih 20 pacijenata u sklopu prijetransplantacijske obrade ovom pretragom se uspjelo adekvatno prikazati morfologiju zdjeličnih arterija i vena, uključujući i prikaz kalcificiranosti arterija, a bez ikakvih neželjenih događaja, uključujući i nefrotoksičnost ${ }^{13}$. Prikaz venskog sustava bio je bolji nego primjenom CT-a.

U konačnici za procjenu krvnih žila može se koristiti i subtrakcijska digitalna angiografija, ali se ona zbog svoje invazivnosti koristi tek u krajnje

Evaluacija krvnih žila primatelja vrlo je bitna u prijetransplantacijskoj obradi. Najtočniji rezultati dobivaju se korištenjem kompjutorizirane tomografije, te se ona smatra zlatnim standardom u analizi krvnih žila primatelja.

nejasnim slučajevima i ako je potrebna endovaskularna intervencija.

Škotska studija pokazala je kako je od 187 pacijenata u kojih je učinjena standardna prijeintransplantacijska obrada (u to vrijeme RTG snimka zdjelice), njih 39,5\% imalo umjerene ili ekstenzivne kalcifikacije te su shodno tadašnjem protokolu povrgnuti CT angiografiji ${ }^{4}$. Njih 21,9\% je nakon toga pregleda maknuto s liste čekanja zbog ekstenzivnih kalcifikacija ilijačnih arterija.

U 24,3\% pacijenata prijeoperacijski CT je odredio stranu na koju će se učiniti transplantacija. U 22 pacijenata je došlo do razvoja vaskularnih komplikacija. Od toga su u njih 19/22 (86,4\%) bile prisutne umjerene do ekstenzivne vaskularne kalcifikacije. Autori zaključuju kako je RTG snimka zdjelice korisna pretraga kao metoda probira, kako bi se identificirali oni pacijenti koji zahtijevaju detaljniju obradu krvnih žila prije transplantacije $^{4}$.

Aalten i suradnici su prospektivno analizirali mogućnosti dokazivanja kalcificiranosti ilijačnih arterija korištenjem RTG snimke zdjelice i razvoja arterijskih komplikacija nakon transplantacije bubrega $^{5}$. Vaskularne kalcifikacije su prijeoperacijski pronađene u 30,2 \% pacijenata, a intraoperativno u $35 \%$ pacijenata. Senzitivnost RTG snimke zdjelice je bila $48 \%$, a specifičnost $82 \%$. Tehnički problemi anastomoziranja arterija zbog prisustva kalcifikacija bili su prisutni u oko $5 \%$ pacijenata. Negativna prediktivna vrijednost RTG snimka za 
nastanak komplikacija arterijske anastomoze bila je $99 \%$, a pozitivna prediktivna vrijednost $14 \%$. Autori su zaključili kako RTG snimka nije pouzdana metoda u otkrivanju vaskularnih kalcifikacija zdjeličnih arterija, a problemi anastomoziranja zbog kalcificiranosti arterija su rijetki ako nema prisutnih kalcifikacija na RTG snimci ${ }^{5}$.

$U$ obje ove studije se za ocjenu kalcificiranosti zdjeličnih arterija dominantno koristila RTG snimka zdjelice. Također je i bodovni sustav bio subjektivan i relativno jednostavan, gdje su se kalcifikacije najčešće određivale opisno kao, primjerice, bez kalcifikacija, minimalne, umjerene i ekstenzivne. Korištenje CT-a daleko je bolja metoda u evaluaciji krvnih žila.

Davis i suradnici ispitivali su povezanost stupnja kalcificiranosti ilijačnih arterija utvrđenih CT pretragom i ishoda transplantacije ${ }^{7}$. Kalcificiranost arterija određivana je u tri kategorije (morfologija, duljina i opseg kalcifikacija) od kojih je svaka zasebno bodovana. Stariji pacijenti i dijabetičari imali su značajno veću kalcificiranost arterija. Multivarijantna analiza pokazala je kako je samo određivanje morfologije kalcifikacija arterijskog segmenta korištenog za arterijsku anastomozu bio neovisni prognostički čimbenik većeg stupnja kirurške zahtjevnosti operacije i veće učestalosti odgođene funkcije presatka. No, pacijenti s na CT dokazanim kalcifikacijama imali su niže jednogodišnje preživljenje u odnosu na one bez kalcifikacija. Autori zaključuju kako je korištenje CT-a za određivanje kalcificiranosti arterija pogotovo korisno u pacijenata starije dobi i onih sa šećernom bolešću, kako bi se odabralo optimalno mjesto za arterijsku anastomozu i na taj način poboljšao ishod transplantacije. U drugoj studiji prikazano je kako je na osnovi CT nalaza ilijačnih arterija $29 \%$ pacijenata bilo isključeno s liste čekanja zbog opsežnih kalcifikacija ilijačnih arterija ${ }^{6}$. Prije spomenute studije pokazuju kako je CT pouzdana metoda za procjenu kalcificiranosti ilijačnih arterija u pacijenata koji se spremaju za transplantaciju bubrega6.

Studije su pokazale različitu povezanost kalcificiranosti ilijačnih arterija i preživljenja grafta i pacijenata, a rezultati tih studija proturječni su ${ }^{4,5,7,14,15}$. Davis je pokazao kako prisutnost kalcifikacija značajno smanjuje preživljenje u odnosu na pacijente koji nisu imali kalcifikacije ${ }^{7}$. Chavent i suradnici analizirali su utjecaj kalcificiranosti aorte i ilijačnih arterija na preživljenje grafta i pacijenata te na pojavnost kardiovaskularnih zbivanja u pacijenata $\mathrm{s}$ transplantiranim bubregom ${ }^{14}$. Prema njihovim rezultatima aortoilijačne kalcifikacije nisu dovele do smanjenja preživljenja pacijenata i grafta, ali su utjecale na pojavnost kardiovaskularnih zbivanja ${ }^{14}$. Disthabanchong i suradnici prospektivno su ispitivali povezanost kalcifikacija aorte i zdjeličnih arterija prikazanih RTG snimkom s ukupnim mortalitetom $u$ pacijenata $s$ kroničnom bubrežnom bolešću podijeljenih u tri skupine (transplantirani pacijenti, pacijenti na hemodijalizi i oni koji još nisu započeli dijalitičko liječenje). Istraživanje je pokazalo kako je stupanj kalcificiranosti zdjeličnih arterija neovisni prognostički čimbenik mortaliteta pacijenata u sve tri skupine pacijenata ${ }^{15}$.

lako smo dugi niz godina za ocjenu kalcificiranosti ilijačnih arterija koristili RTG snimku zdjelice, često uz dodatak dopplerskog pregleda, posljednjih godina koristimo CT. U pacijenata koji su već započeli s dijalitičkim liječenjem radimo $\mathrm{CT}$ s kontrastom ili CT angiografiju, a kod pacijenata koji još uvijek nisu započeli s dijalitičkim liječenjem radimo nativni $\mathrm{CT}$. CT abdomena i zdjelice s kontrastom je senzitivnija metoda od nativnoga CT-a, ali i nativni CT je daleko senzitivnija metoda od RTG snimke zdjelice. Prikazani rezultati koji obuhvaćaju i najrecentnije razdoblje pokazali su nam kako je korištenje CT-a veoma korisno. Vidljivo je kako $78 \%$ naših pacijenata ima arterijske kalcifikacije u području ilijačnih arterija. Prema našem iskustvu, koje je poduprto rezultatima iz literature, zasigurno najveća vrijednost CT oslikavanja ilijačnih arterija je mogućnost određivanja strane transplantacije i arterijskog segmenta pogodnog za arterijsku anastomozu. Upravo je CT bio presudna dijagnostička pretraga da u 5,4 \% naših pacijenata transplantaciju učinimo ipsilateralno. Arterijske kalcifikacije imaju veliku kliničku važnost jer njihova prisutnost govori u prilog mogućeg otežanog anastomoziranja krvnih žila. U slučaju izrazito opsežnih kalcifikacija anastomozu nije niti moguće učiniti te treba odrediti drugo mjesto anastomoziranja. Naime, u pacijenata u kojih to nije ispravno procijenjeno može se dogoditi da moraju biti učinjene dvije incizije kako bi se pronašla po- 
godna arterija. Alternativno se u takvih pacijenata može učiniti medijana laparotomija, pa ako se adekvatno mjesto za arterijsku anastomozu ne može pronaći na jednoj strani, transplantacija se, koristeći isti rez, može učiniti na drugoj strani. Uporabom CT-a u prijetransplantacijskoj obradi primatelja nemogućnost pronalaska mjesta za arterijsku anastomozu svodi se na najmanju moguću mjeru.

Nedostatak naše studije je u tome što se radi o retrospektivnoj studiji koja uključuje samo jedan transplantacijski centar uz relativno mali broj pacijenata. Uključivanjem više centara iz različitih zemalja sigurno bi se dobio bolji uvid u učestalost i distribuciju kalcificiranosti zdjeličnih arterija kod pacijenata s transplantiranim bubregom.

\section{ZAKLJUČAK}

Većina naših pacijenata u kojih je učinjena transplantacija bubrega ima prisutne kalcifikacije na ilijačnim arterijama. Kalcifikacije su bile češće na zajedničkim ilijačnim arterijama nego na vanjskoj ilijačnoj arteriji. Raspodjela i proširenost kalcifikacija utjecali su na određivanje kirurškog pristupa krvnim žilama prilikom transplantacije bubrega u naših pacijenata.

Izjava o sukobu interesa: Autori izjavljuju da ne postoji sukob interesa.

\section{LITERATURA}

1. Hrvatsko društvo za nefrologiju, dijalizu i transplantaciju [Internet]. Hrvatski registar nadomještanja bubrežne funkcije - izvještaj za 2014. godinu. [cited 2019 December 22]. Available from: https://www.hdndt.org/registar-nadomjestanja-bubrezne-funkcije.

2. Goldsmith D, Covic A, Sambrook PA, Ackrill P. Vascular calcification in long-term hemodialysis patients in a single unit: a retrospective analysis. Nephron 1997;77:37-43.

3. Jono $S$, McKee MD, Murry CE, Shioi A, Nishizawa $Y$, Mori $\mathrm{K}$ et al. Phosphate regulation of vascular smooth muscle cell calcification. Circ Res 2000;87:E10-7.
4. Aitken E, Ramjug S, Buist L, Kingsmore D. The prognostic significance of iliac vessel calcification in renal transplantation. Transplant Proc 2012;44:2925-31.

5. Aalten J, Dekker HM, Van Der Vliet JA, Hoitsma AJ. Does a plain X-ray of the pelvis predict arterial complications in renal transplantation ? A prospective study. Nephrol Dial Transplant 2011;26:2007-12.

6. Andres A, Revilla Y, Ramos A, Gonzalez E, Vereda MS, Praga $\mathrm{M}$ et al. Helical computed tomography angiography is the most efficient test to assess vascular calcifications in the iliac arterial sector in renal transplant candidates. Transplant Proc 2003;35:1682-3.

7. Davis B, Marin D, Hurwitz LN, Ronald J, Ellis MJ, Ravindra $\mathrm{KC}$ et al. Application of a novel CT-based iliac artery calcification scoring system for predicting renal transplant outcomes. Am J Roentgenol 2016;206:436-41.

8. European Renal Best Practice Transplantation Guideline Development Group. ERBP Guideline on the Management and Evaluation of the Kidney Donor and Recipient. Nephrol Dial Transplant 2013;28:ii1-71.

9. Breda A, Budde K, Figueiredo A, Lledo-Garcia E, Olsburgh J, Regele H. EAU guidelines on renal transplantation. European Association of Urology Guidelines, 2019.

10. Davenport MS, Khalatbari S, Dillman JR, Cohan RH, Caoili EM, Ellis JH. Contrast material-induced nephrotoxicity and intravenous low-osmolality iodinated contrast material. Radiology 2013;267:94-105.

11. Parfrey PS, Griffiths SM, Barrett BJ, Paul MD, Genge M, Withers $\mathrm{J}$ et al. Contrast material-induced renal failure in patients with diabetes mellitus, renal insufficiency, or both. A prospective controlled study. N Engl J Med 1989; 320:143-9.

12. Collidge TA, Thomson PC, Mark PB, Traynor JP, Jardine AG, Morris ST et al. Gadolinium-enhanced MR imaging and nephrogenic systemic fibrosis:retrospective study of a renal replacement therapy cohort. Radiology 2007; 245:168-75.

13. Stoumpos S, Hennessy M, Vesey AT, Radjenovic A, Kasthuri R, Kingsmore DB et al. Ferumoxytol-enhanced magnetic resonance angiography for the assessment of potential kidney transplant recipients. Eur Radiol 2018;28:115-23.

14. Chavent B, Maillard N, Boutet C, Albertini JN, Duprey A, Favre JP. Prognostic value of aortoiliac calcification score in kidney transplantation recipients. Ann Vasc Surg 2017;44:242-52.

15. Disthabanchong S, Vipattawat K, Phakdeekitcharoen B, Kitiyakara C, Sumethkul V. Abdominal aorta and pelvic artery calcifications on plain radiographs may predict mortality in chronic kidney disease, hemodialysis and renal transplantation. Int Urol Nephrol 2018;50:355-64. 